\title{
Students' Creative Thinking in Solving Mathematical Problems Using Various Representations
}

\author{
Dwi Novitasari \\ Mathematics Education Study Program \\ Universitas Mataram \\ Mataram, Indonesia
}

\author{
Tabita Wahyu Triutami \\ Mathematics Education Study Program \\ Universitas Mataram \\ Mataram, Indonesia
}

\author{
Nourma Pramestie Wulandari* \\ Mathematics Education Study Program \\ Universitas Mataram \\ Mataram, Indonesia \\ nourmapw@unram.ac.id
}

\author{
Abdul Rahman \\ Mathematics Education Study Program \\ Universitas Negeri Makassar \\ Makassar, Indonesia
}

\author{
Alimuddin Alimuddin \\ Mathematics Education Study Program \\ Universitas Negeri Makassar \\ Makassar, Indonesia
}

\begin{abstract}
The present study aims at identifying students' creative thinking in applying various representations to solve mathematical problems. This descriptive study was done in a senior high school in Makassar, Indonesia. The subjects were two selected students with high spatial-visual intelligence taken from 62 grade XI students who participated in the pre-test. The data were gathered from students' written work in problem solving and visual-spatial test, and interview. The analysis of data was done qualitatively using deductive approach. The research showed that the students' creative thinking was involving the symbolic and visual representation, and visual-spatial intelligence. The steps of creative thinking can be explained in four steps, as follows: (1) Preparation, including information gathering (symbolic representation) and problem translating, (2) Incubation, including ideas and conjectures constructing, (visual and symbolic representations), connecting and recalling the appropriate concepts to solve the problem (3) Illumination, including ideas designing and applying (visual representation) and (4) Verification, including solution testing (symbolic representation) and conclusion making.
\end{abstract}

Keywords-creative thinking, problem solving visual representation, symbolic representation

\section{INTRODUCTION}

Creativity is one of the important aspects in learning mathematics [1],[2]\&[3]. According to Gardner, creativity is a multiple intelligences that activate the brain function to develop cognitive scheme which is beneficial to explain the abstract concept that enable students to gain better understanding in learning mathematics [4].

In 1950, Guilford et al. introduced Structure of Intellect which emphasized three important aspects in creativity, i.e. fluency, flexibility and originality [5]. Furthermore, Wallas explained the four steps of critical thinking involving Preparation, Incubation, Illumination and Verification [6], while Anderson \& Krathwohl formulated three stages of creative thinking, i.e. Generating, Planning and Producing [7].

Basically, every student has potency to be creative. However, in traditional classroom, teacher mostly presents routine problems which are algorithmic and mechanistic.
This kind of problem usually has one correct answer. It makes the students' creativity is not fully developed.

Besides creative thinking, representation plays crucial role as it is targeted as one of five important skills accomplished through the learning of mathematics [8]. In general, mathematical representation can be classified in to visual (pictures, diagrams, graphics or tables) and symbolic (mathematical statements, notation, numeric and algebraic symbols) and verbal representations [9]. The ability to use different type of representations reflects the students' conceptual understanding of the problem [10].

The use of representation will support the student in creating more concrete mathematical ideas since the complex problem can be simplified by using appropriate mathematical representation [8], [11], [12]. In addition, different uses of representations can be useful support to enable students in learning as can be seen in numerous studies (see [13], $[14] \&[15])$. In the previous studies, the students were reported to be aware in using visual and symbolic representations in their mathematical problem solving [16], [17]\&[18]. However, students' lack of details contributed to the inability of constructing a proper representation of mathematical objects.

Generally, the students' ability in making representation are varied due to many factors, including their multiple intelligences. It is further recognized to significantly contributes to students' learning achievement in mathematics [19]\&[20] and problem solving ability [21]. One type of multiple intelligences is visual-spatial intelligence which is the skill to accurately understand, transform and modify their visual experiences [22]. It is also consiered as the ability to imagine different position and shape or manipulate objects in their minds [23].

Previous researches mostly focused on students' creative thinking in solving mathematical problems by using various representation. In the presentreport, we investigated the contribution of the students' visual-spatial ability toward their problem-solving ability by thinking creatively and applying various representations. The results of the study might be useful for teachers to guide the students in 
developing their critical thinking and flexibility in using different representations.

\section{METHODS}

As the aim of the study was to describe the students' creative thinking in solving mathematics problems using various representations, and descriptive study has been chosen as the design of the research. The overall participants were 62 students in grade eleventh of a senior high school in Makassar, Indonesia. The participants were given a visualspatial test and from the population, 2 subjects with high visual-spatial intelligence were chosen as the subject of the present study.

The data were gathered from students' work in problem solving test and interview. The data were analyzed qualitatively using qualitative content analysis with deductive approach [25]. There are four steps in the analysis including data preparation, organization, presentation and estimation. This technique is deliberately chosen as it is usefulness to clearly describe every creative thinking process.

The students' responses were analyzed based on its creativity and representation abilities using the following indicators. There are four indicators in creative thinking process as adapted from Wallas, Anderson \& Krathwohl [7] and Polya problem solving steps [24]. The first indicator was Preparation, including information gathering (symbolic representation) and problem translating. The second indicator was Incubation, including ideas and conjectures constructing, (visual and symbolic representations), connecting and recalling the appropriate concepts to solve the problem. The third indicator was Illumination, including ideas designing and applying (visual representation). The fourth indicator was Verification, including solution testing (symbolic representation) and conclusion making.

In addition, the indicators for mathematical representation can be classified as: (1) Visual Representation, e.g. making a pictures, graphs or tables from available information; (2) Symbolic Representation, e.g. making and applying the mathematical equations or expressions to solve the problem [18].

\section{RESULTS AND DISCUSSION}

In the following discussion, we describe how the subjects worked on problem solving test to investigate their creative thinking and the application of mathematical representations.

In the Preparation stage, both of the students were gathering information given in the problem and wrote the symbolic representation of it. S2 provided more details as can be seen in Fig.1.

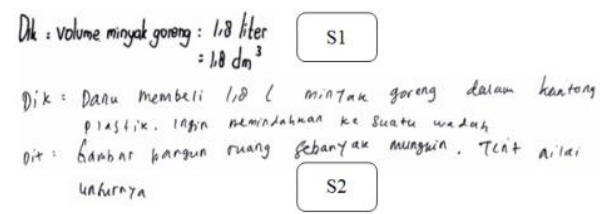

Fig. 1. Symbolic Representation of S1 and S2
S2

Given :Danu bought 1.8 liter oil put in a plastic and he wants to move it to a container.

Asked :Draw as many as possible three-dimensional spaces [as container] and determine its size

During the interview, it was found that in this process, both of subjects were translated the problem visually in their mind and then wrote the symbolic representation to help them in constructing strategies to solve the problem.

In the Incubation stage, both S1 and S2 employed their visual-spatial intelligences to imagine or represent the shape of the container that will be used as the solution for the given problem. S1 connected the concepts and principles relate to any three-dimensional shape will be able to create with adjusted size, except cube since it has to have equal sizes.

Since S1 thought the ideas were ready to be implemented and he proved in in Verification stage, S1 made another conjecture by combining two three-dimensional shapes. Here, S1 modified the visual experiences into visual representations.

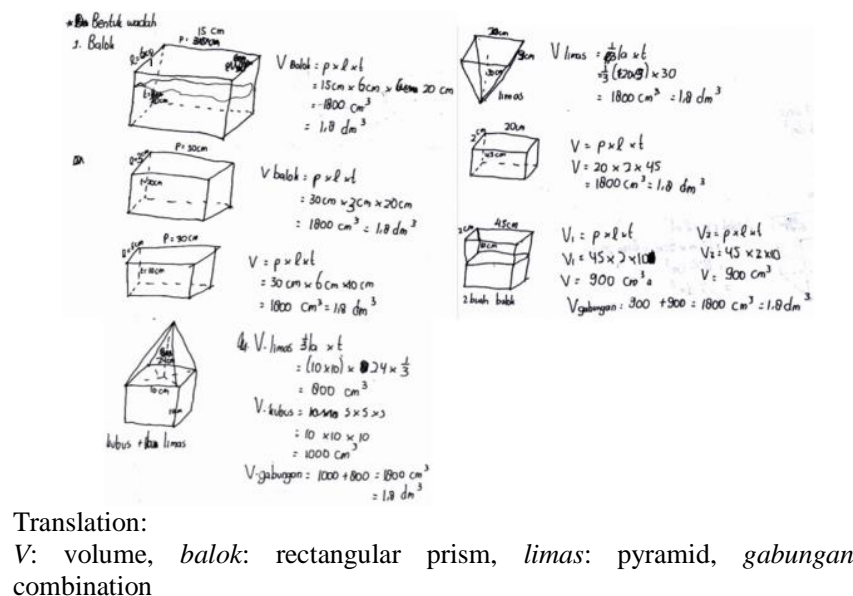

Fig. 2. Symbolic and Visual Representation of S1

In the Illumination stage, $\mathrm{S} 1$ started the work by choosing the arbitrary size for each sides of the shape which is represented visually using a picture. S1 firstly used the rectangular prism and then combine 2 three-dimensional spaces into 1 shape using the ability to transform and modify the visual experiences. S1 checked the volume in the combination objects and ensured that the total of volume will be 1.8 liter. As can be seen in Fig.2, there are seven solutions $\mathrm{S} 1$ offered towards the problem.

Meanwhile S2 had difficulty in his trial if the shape of the container was cylinder. Using the similar process as S1, S2 offered five solutions as can be seen in Fig.3. The S2 works involved an accurate skill in perceiving visual world, one of the indicators of visual-spatial intelligence. 


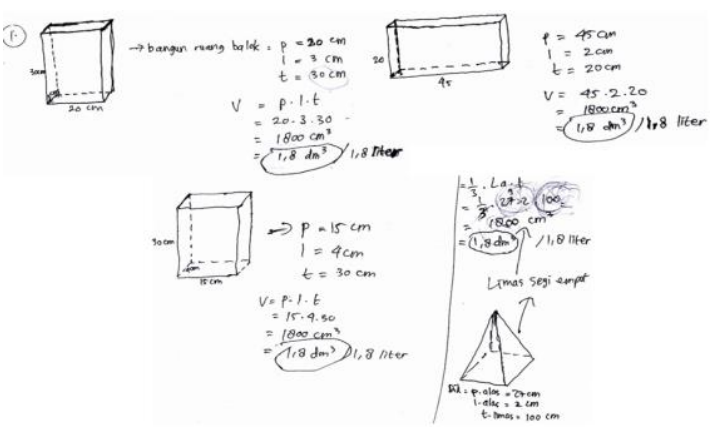

Fig. 3. Symbolic and Visual Representation of S2

In the Verification stage, both of the subjects verify the correctness of the solution using working backward procedures. They also created a conclusion and explained it verbally during interview, even though they not wrote it on their test. Overall, the creative thinking using various mathematics representations of the students with high visualspatial intelligence can be illustrated as in Fig.4.

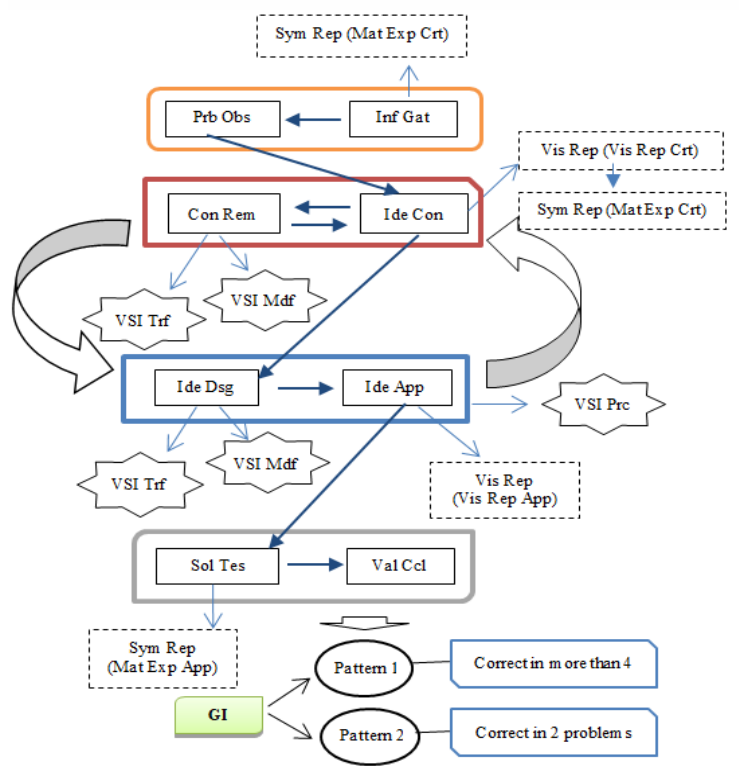

Fig. 4. Creative Thinking Process Using Various Representations

TABLE 1. CODE FOR STUDENTS' THINKING PROCESS

\begin{tabular}{|l|l|}
\hline Representation & Code \\
\hline Symbolic Representation & Sym Rep \\
\hline Visual Representation & Vis Rep \\
\hline Visual Representation Creation & Vis Rep Crt \\
\hline Mathematical Expression Creation & Mat Exp Crt \\
\hline $\begin{array}{l}\text { Visual Representation Application to Solve } \\
\text { Mathematics Problem }\end{array}$ & Vis Rep App \\
\hline $\begin{array}{l}\text { Mathematical Expression Application to Solve } \\
\text { Mathematics Problem }\end{array}$ & Mat Exp App \\
\hline $\begin{array}{l}\text { Visual Spatial Intelligences to Transform Visual } \\
\text { Experiences }\end{array}$ & VSI Trf \\
\hline $\begin{array}{l}\text { Visual Spatial Intelligences to Modify Visual } \\
\text { Experiences }\end{array}$ & VSI Mdf \\
\hline $\begin{array}{l}\text { Visual Spatial Intelligences to Perceiving Visual } \\
\text { Experiences }\end{array}$ & VSI Prc \\
\hline Problem Observation/Translation & Prb Obs \\
\hline Information Gathering & Inf Gat \\
\hline Ideas Construction & Ide Con \\
\hline Remember Concepts, Ideas and Principles & Con Rem \\
\hline Ideas Design & Ide Dsg \\
\hline Ideas Application & Ide App \\
\hline
\end{tabular}

\begin{tabular}{|l|l|}
\hline Representation & Code \\
\hline Solution Testing & Sol Tes \\
\hline Valid Conclusion & Val Ccl \\
\hline General Ideas & GI \\
\hline $\begin{array}{l}\text { Construct 1 three-dimensional shape, determine its size } \\
\text { by trial and error strategy }\end{array}$ & Pattern 1 \\
\hline $\begin{array}{l}\text { Construct 2 three-dimensional shape, determine its size } \\
\text { by trial and error strategy }\end{array}$ & Pattern 2 \\
\hline Preparation Stage & \\
\hline Incubation Stage & \\
\hline Illumination Stage & \\
\hline Verification Stage & \\
\hline
\end{tabular}

Based on Fig.5, the creative thinking process of the students with high visual-spatial intelligence were slightly different with the developed model by Wallas and Anderson $\&$ Krathwohl. The differences were found in Preparation and Incubation stages. During Preparation, subjects gathered all of the relevant information before looking at the problem. While in Incubation, the subjects constructed conjectures first, before recalling and connecting the relevant concepts, principles or properties. After that, the subjects solve the problem with the support of their abilities in transforming visual experiences. The next stages in Illumination and Verification were proceed in line with the results of Wallas and Anderson \& Krathwohl.

The students were also performed good abilities in planning and perceiving the visual experiences into their problem-solving procedures. It is show that their creative thinking process involved in more than one types of representation, in this case visual and symbolic representations. Using the support of representation, the students got better understanding to solve the problem [12], [17], [26].

Furthermore, the visual-spatial abilities of the subject played important roles in their problem solving. It can be seen that students' ability in creating appropriate pictures [19], [20], [22], [27]. One remark according to this, even though both students fluently proposed the solutions and provided more than four alternatives, if we closely observe their works, it can be seen that both of them made a nonequivalent measurement in their drawing. In Fig.5., S1 made the length of $20 \mathrm{~cm}$ longer than $43 \mathrm{~cm}$ and $2 \mathrm{~cm}$ seemed to be too long, not in proper proportion. Also, S2 made the size of $27 \mathrm{~cm}, 2 \mathrm{~cm}$ and $100 \mathrm{~cm}$ without significant difference.
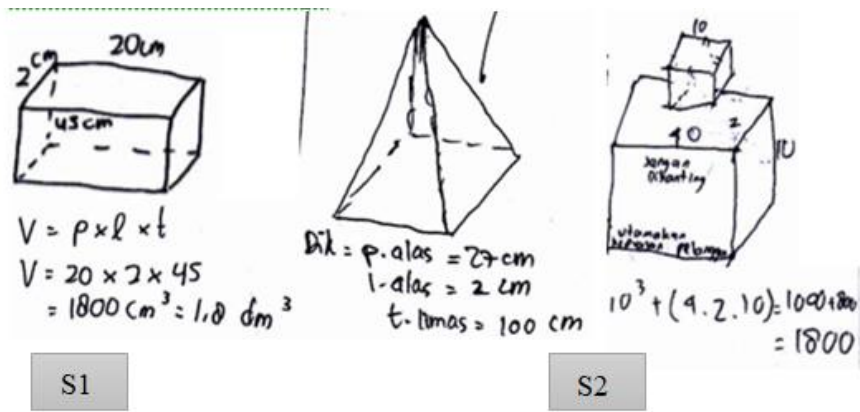

$=1800$

Fig.5. Non-proportional Size in Visual Representation of S1 and S2

Regarding the flexibility aspect, the students applied their ideas differently, but using one three ideas as follows: (1) 
single shape, (2) combine two similar shapes and (3) combine two different shapes. In term of originality, the students' ideas to combine two three-dimensional spaces were new for them and it was originally developed by their own thinking after imaging what kind of container that will be useful to keep the oil.

\section{CONCLUSION}

Based on the analysis of the study, it can be concluded that the steps of creative thinking can be explained in four steps, which are Preparation, including information gathering (symbolic representation) and problem translating; Incubation, including ideas and conjectures constructing, (visual and symbolic representations), connecting and recalling the appropriate concepts to solve the problem; Illumination, including ideas designing and applying (visual representation); and Verification, including solution testing (symbolic representation) and conclusion making.

During the process, the students made mistakes in creating visual representation, i.e. inaccurate size comparison of the sides of the three-dimensional shape. Furthermore, the creativity in problem solving involved two types of representation, symbolic and visualization. Also, the visual-spatial intelligence of the students was applied when they accurately transforming, modifying and perceiving their visual. Reflected from the results, teachers should encourage students to develop critical thinking abilities by using various representations.

\section{REFERENCES}

[1] E. L. Mann, "Creativity: The essence of mathematics," J. Educ. Gift., vol. 30, no. 2, pp. 236-260, 2006, doi: 10.4219/jeg-2006-264.

[2] R. Lince, "Creative Thinking Ability to Increase Student Mathematical of Junior High School by Applying Models Numbered Heads Together," J. Educ. Pract., vol. 7, no. 6, pp. 206-212, 2016.

[3] L. Puspitasari, A. In'am, and M. Syaifuddin, "Analysis of Students' Creative Thinking in Solving Arithmetic Problems," Int. Electron. J. Math. Educ., vol. 14, no. 1, pp. 49-60, 2018, doi: 10.12973/iejme/3962.

[4] K. M. A. Fauzi, I. W. Dirgeyase, and A. Priyatno, "Building Learning Path of Mathematical Creative Thinking of Junior Students on Geometry Topics by Implementing Metacognitive Approach," Int. Educ. Stud., vol. 12, no. 2, pp. 57-66, 2019, doi 10.5539/ies.v12n2p57.

[5] B. Sriraman and K. H. Lee, The Elements of Creativity and Giftedness in Bharath Sriraman and The Elements of Creativity and Giftedness in Mathematics, 1st ed. Sense Publishers, 2011.

[6] E. S. Smith, "Wallas ' Four -Stage Model of The Creative Process : More Than Meets The Eye ?," Creat. Res. J., vol. 27, no. 4, pp. 342352, 2015, doi: 10.1080/10400419.2015.1087277.

[7] D. Novitasari, "Analisis Kreativitas Siswa Dalam Pemecahan Masalah Visual Spasial dan Logis Matematis Ditinjau Dari Gender," JMPM J. Media Pendidik. Mat., vol. 5, no. 2, pp. 75-83, 2017.

[8] NCTM, Principles and Standar for School Mathematics. United States of America: NCTM, 2000.

[9] G. F. Khairunnisa, A. Rahman, and H. Susanto, "Keberhasilan Siswa dalam Menyelesaikan Soal Cerita Berdasarkan Kemampuan Membuat Berbagai Representasi Matematis," J. Pendidik. Teor. Penelit. dan Pengemb., vol. 3, no. 6, pp. 723-730, 2018, doi: 10.17977/jptpp.v3i6.11117.

[10]R. Kang and D. Liu, "The Importance of Multiple Representations of Mathematical Problems: Evidence from Chinese Preservice Elementary Teachers' Analysis of a Learning Goal,” Int. J. Sci. Math. Educ., vol. 16, no. 1, pp. 125-143, 2016, doi: 10.1007/s10763-0169760-8.

[11] M. S. Noto, W. Hartono, and M. D. Sundawan, “Analysis of Students
Mathematical Representation and Connection on Analytical Geometry Subject," Infin. J. Math. Educ., vol. 5, no. 2, pp. 99-108, 2016, doi: 10.22460/infinity.v5i2.216.

[12]Nizaruddin, Muhtarom, and Y. H. Murtianto, "Exploring of Multi Mathematical Representation Capability in Problem Solving on Senior High School Students," Probl. Educ. 21st Century, vol. 75, no. 6, pp. 591-598, 2013

[13]R. A. Apsari, R. I. I. Putri, Sariyasa, M. Abels, and S. Prayitno, "Geometry representation to develop algebraic thinking: A recommendation for a pattern investigation in pre-algebra class," $J$. Math. Educ., vol. 11, no. 1, pp. 45-58, 2020, doi: 10.22342/jme.11.1.9535.45-58.

[14]R. A. Apsari, S. Sariyasa, R. I. I. Putri, G. Gunawan, and S. Prayitno, "Understanding Students' Transition from Arithmetic to Algebraic Thinking in the Pre-Algebraic Lesson Understanding Students Transition from Arithmetic to Algebraic Thinking in the Pre-Algebraic Lesson," J. Phys. Conf. Ser., vol. 1471, pp. 1-7, 2020, doi: 10.1088/1742-6596/1471/1/012056

[15]A. F. Samsuddin and H. Retnawati, "Mathematical representation: The roles, challenges and implication on instruction," J. Phys. Conf. Ser., vol. 1097, no. 1, 2018, doi: 10.1088/1742-6596/1097/1/012152.

[16]R. B. Anwar, I. Yuwono, and A. Rahman, "Mathematical representation by students in building relational understanding on concepts of area and perimeter of rectangle," vol. 11, no. 21, pp. 2002 2008, 2016, doi: 10.5897/ERR2016.2813.

[17]R. B. Anwar and D. Rahmawati, "Symbolic and Verbal Representation Process of Student in Solving Mathematics Problem Based Polya's Stages," Int. Educ. Stud., vol. 10, no. 10, pp. 20-28, 2017, doi: 10.5539/ies.v10n10p20.

[18]L. Hijriani, S. Rahardjo, and R. Rahardi, "Deskripsi Representasi Matematis Siswa SMP dalam Menyelesaikan Soal PISA," J. Pendidik. Teor. Penelitian, dan Pengemb., vol. 3, no. 5, pp. 603-607, 2018, doi: 10.17977/jptpp.v3i5.11061.

[19]I. G. A. N. T. Jayantika, I. M. Ardana, and I. G. P. Sudiarta, "Kontribusi Bakat Numerik, Kecerdasan Spasial dan Kecerdasan Logis Matematis Terhadap Prestasi Belajar Matematika Siswa SD Negeri di Kabupaten Buleleng," e-Journal Progr. Pascasarj. Univ. Pendidik. Ganesha, vol. 2, no. 1, pp. 1-12, 2013, doi: 10.23887/jppm.v2i2.981.

[20] Y. R. Ahvan and H. Z. Pour, "The Correlation of Multiple Intelligences for The Achievements of Secondary Students," Acad. Journals, vol. 11, no. 4, pp. 141-145, 2016, doi: 10.5897/ERR2015.2532.

[21]C. Charcharos, M. Kokla, and E. Tomai, "Investigating the Influence of Spatial Thinking in Problem Solving," Agile, no. June, 2016, doi: 10.13140/RG.2.1.4186.0729.

[22]Y. H. Gumilar and N. Nandi, "The Student 's Spatial Intelligence Level in Senior The Student' s Spatial Intelligence Level in Senior High School," IOP Conf. Ser. Earth Environ. Sci., vol. 145, no. 1, 2018, doi: 10.1088/1755-1315/145/1/012094

[23]K. Yenilmez, "Investigation of the Relationship between the Spatial Visualization Success and Visual / Spatial Intelligence Capabilities of Sixth Grade Students," Int. J. Instr., vol. 8, no. 1, pp. 189-204, 2015.

[24]G. Polya, How To Solve It: A New Aspect of Mathematical Method, 2nd ed. New Jersey: Pricenton University Press, 1973.

[25] S. Elo and H. Kyngas, "The qualitative content analysis," J. Adv. Nurs., vol. 62 , no. 1, pp. 107-115, 2008, doi: 10.1111/j.13652648.2007.04569.x.

[26]D. Rahmawati, Purwanto, Subanji, E. Hidayanto, and R. B. Anwar, "Process of Mathematical Representation Translation from Verbal into Graphic," Int. Electron. J. Math. Educ., vol. 12, no. 3, pp. 367-381, 2017.

[27]M. Palmiero and S. Narayanan, "Creativity and Spatial Ability: A Critical Evaluation Massimiliano Palmiero and Narayanan Srinivasan Introduction," 2010. 